\title{
IDENTIFIKASI KESALAHAN MAHASISWA PROGRAM STUDI PENDIDIKAN FISIKA SEMESTER I DALAM MENYELESAIKAN SOAL TURUNAN
}

\author{
Gandung Sugita \\ gandungpplw@gmail.com
}

\begin{abstract}
Abstrak: Permasalahan pada penelitian ini adalah kesulitan mahasiswa pada materi Turunan yang menyebabkan mahasiswa sering melakukan kesalahankesalahan dalam menyelesaikan soal Turunan. Berdasarkan permasalahan tersebut, penelitian ini bertujuan mendeskripsikan kesalahan-kesalahan yang dilakukan mahasiswa Program Studi Pendidikan Fisika semester I tahun ajaran 2016/2017 dalam menyelesaikan soal Turunan. Jenis penelitian ini adalah penelitian kualitatif dengan pendekatan deskriptif. Penelitian ini akan mendeskripsikan kesalahan-kesalahan mahasiswa Program Studi Pendidikan Fisika semester I tahun ajaran 2017/2018 dalam menyelesaikan soal Turunan. Pengumpulan data dilakukan dengan tes dan wawancara. Pemberian tes bertujuan memperoleh data mengenai kesalahan-kesalahan mahasiswa dalam menyelesaikan soal Turunan. Wawancara tidak terstruktur dilakukan untuk memastikan letak kesalahan mahasiswa dalam menyelesaikan soal Turunan. Berdasarkan analisis data diperoleh kesimpulan bahwa kesalahan yang dilakukan mahasiswa Prodi Pendidikan Fisika semester I tahun ajaran 2017/2018, dalam menyelesaikan soal Turunan, yaitu: 1. Untuk soal nomor 1: (a) tidak dapat mencari turunan satu fungsi menggunakan definisi. (b) salah dalam mensubsitusi $\mathrm{f}(\mathrm{x})$ menjadi $\mathrm{f}(\mathrm{x}+\mathrm{h})$ 2. ntuk soal nomor 2 : (a) salah dalam menurunkan perkalian dua fungsi, (b) salah dalam menurunkan pembagi dua fungsi, (c) menganggap $\pi$ merupakan variabel (belum dapat membedakan variabel dan konstan)
\end{abstract}

Kata kunci: Identifikasi kesalahan mahasiswa, menyelesaikan soal Turunan

Pendidikan nasional bertujuan mengembangkan potensi peserta didik agar menjadi manusia yang beriman dan bertaqwa kepada Tuhan Yang Maha Esa, berahlak mulia, sehat, berilmu, cakap, kreatif, mandiri, dan menjadi warga Negara yang demokrati s serta bertangungjawab. Sehubungan dengan tujuan tersebut, peningkatan kualitas pendidikan merupakan tanggungjawab pendidikan tinggi, khususnya tenaga pengajar (dosen).Dosen adalah salah satu profesi yang turut berperan meningkatkan kualitas pembelajaran di kelas. Untuk meningkatkan kualitas pembelajaran di kelas beberapa hal telah dilakukan, antara lain: membuat bahan ajar, menggunakan model yang cocok dan melaksanakan perbaikan pembelajaran, namun, dalam pembelajaran di kelas sering dijumpai beberapa mahasiswa mengalami kesulitan yang menyebabkan kesalahan dalam mengerjakan soal-soal, khususnya soal matematika. Satu diantara penyebab kesalahan mahasiswa dalam mengerjakan soal-soal matematika adalah ketidak pahaman mahasiswa terhadap konsep dan prinsip matematika (Kumalasari, 2013).

Berdasarkan pengalaman tim pengajar pada matakuliah Kalkulus I, materi yang dianggap sulit oleh mahasiswa Program Studi Pendidikan Fisika adalah materi Turunan. Akibatnya mahasiswa sering melakukan kesalahan dalam menyelesaikan soal-soal 
Turunan. Beberapa kesalahan yang dilakukan yaitu: kesalahan menggunakan definisi Turunan, kesalahan menggunakan aturan turunan, dan kesalahan dalam manupulasi aljabar. Jika keadaan ini terus menerus terjadi, maka besar kemungkinan kesulitan pada materi selanjutnya akan terjadi, seperti materi Integral yang memerlukan penguasaan materi Turunan.

Materi Turunan telah dipelajari di SMA/SMK/MA, namun kenyataannya mahasiswa tidak dapat menyelesaikan soal Turunan secara benar. Materi Turunan merupakan salah satu materi pada matakuliah Matematika Dasar. Materi ini dipelajari kembali dengan beberapa pengembangan pada semester I di Program Studi Pendidikan Fisika. Karena materi Turunan merupakan materi pengulangan, maka kami tim pengajar (sekaligus tim peneliti) ingin melihat kesalahan-kesalahan apa yang masih dilakukan mahasiswa setelah mereka memperoleh materi Turunan di sekolah. Dengan mengetahui kesalahan-kesalahan tersebut, tim pengajar akan memperoleh gambaran untuk merencanakan pembelajaran materi Turunan pada matakuliah Matematika Dasar

Tujuan penelitian ini yaitu mendeskripsikan kesalahan-kesalahan yang dilakukan mahasiswa Program Studi Pendidikan Fisika semester Itahun ajaran 2016/2017 dalam menyelesaikan soal Turunan.

\section{METODE PENELITIAN}

Jenis penelitian ini adalah penelitian kualitatif dengan pendekatan deskriptif. Penelitian ini mendeskripsikan kesalahan-kesalahan mahasiswa Program Studi Pendidikan Fisika semester I tahun ajaran 2017/2018 dalam menyelesaikan soal Turunan. Subyek penelitian ini adalah mahasiswa Program Studi PendidikanFisika semester Itahunajaran 2017/2018, yang telah mempelajari materi turunan di SMA/SMK/MA dan melakukan kesalahan dalam menyelesaikan soal Turunan. Pengumpulan data dilakukan dengan tes dan wawancara. Pemberian tes bertujuan memperoleh data mengenai kesalahan-kesalahan mahasiswa dalam menyelesaikan soal Turunan. Wawancara tidak terstruktur dilakukan untuk memastikan letak kesalahan mahasiswa dalam menyelesaikan soal turunan. Teknik analisis data yang digunakan mengacupada model Miles dkk (2014) yaitu Kondensasi data (data Condensation), penyajian data (data display), dan penarikan kesimpulan (conclusions drawing).

\section{HASIL PENELITIAN}

Penelitian ini dilakukan pada mahasiswa kelas C Prodi Pendidikan Fisika, Jurusan Pendidikan MIPA FKIP Universitas Tadulako. Tes ini diberikan untuk melihat kesalahankesalahan yang dilakukan mahasiswa dalam menyelesaikan soal Turunan. Berdasarkan kesalahan-kesalahan tersebut, diharapkan dapat membantu tim pengajar membuat perencanaan pada pembelajaran Turunan.

Seminggu sebelum pelaksanaan tes, disampaikan kepada mahasiswa untuk mempelajari kembali tentang menentukan turunan menggunakan definisi dan aturan turunan yang sudah diperoleh di sekolah. Tes dilaksanakan padatanggal, 27 September 2017 dan diikuti oleh 44mahasiswa. Dari hasil tes diperoleh informasi tentang kesalahan yang dilakukan sebagai berikut. 
a) Kesalahan-kesalahan yang dilakukan mahasiswa untuk soal nomor 1a

a. Kesalahan 1

Jawaban RN

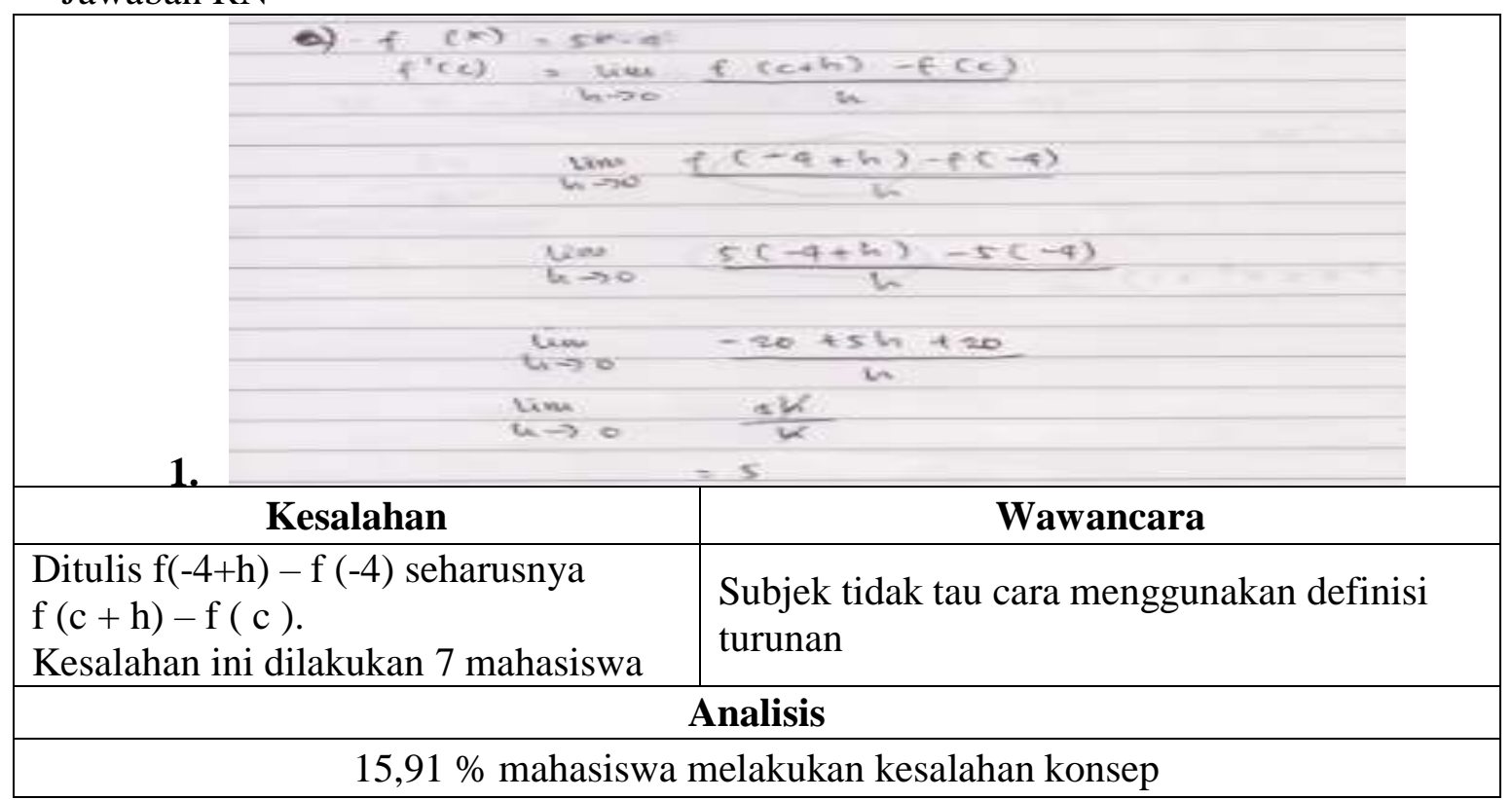

b. Kesalahan 2

Jawaban MI

\begin{tabular}{|c|c|}
\hline St Panyelesaian . & $\rightarrow$ \\
\hline$f(e)=$ & $5 x--4$ \\
\hline$f^{\prime}(c)=$ & $1 \cdot 5 x^{x+1}-4$ \\
\hline$f^{\prime \prime}(e)=$ & $5 x=-4$ \\
\hline$f^{\prime \prime}(c)=$ & $5 \times$ \\
\hline Kesalahan & Wawancara \\
\hline $\begin{array}{l}\text { Tidak menggunakan definisi Turunan } \\
\text { yang diperintahkan untuk soal no. } 1 . \\
\text { Kesalahan ini dilakukan } 8 \text { mahasiswa }\end{array}$ & $\begin{array}{l}\text { Subjek MI mengetahui perintah soal, namun } \\
\text { MI tidak menggunakan definisi turunan yang } \\
\text { diperintahkan pada soal karena tidak tau cara } \\
\text { mengerjakan turunan menggunakan definisi } \\
\text { turunan tersebut }\end{array}$ \\
\hline & Analisis \\
\hline $18,18 \%$ mahasisw & melakukan kesalahan konsep \\
\hline
\end{tabular}


c. Kesalahan 3

Jawaban SN

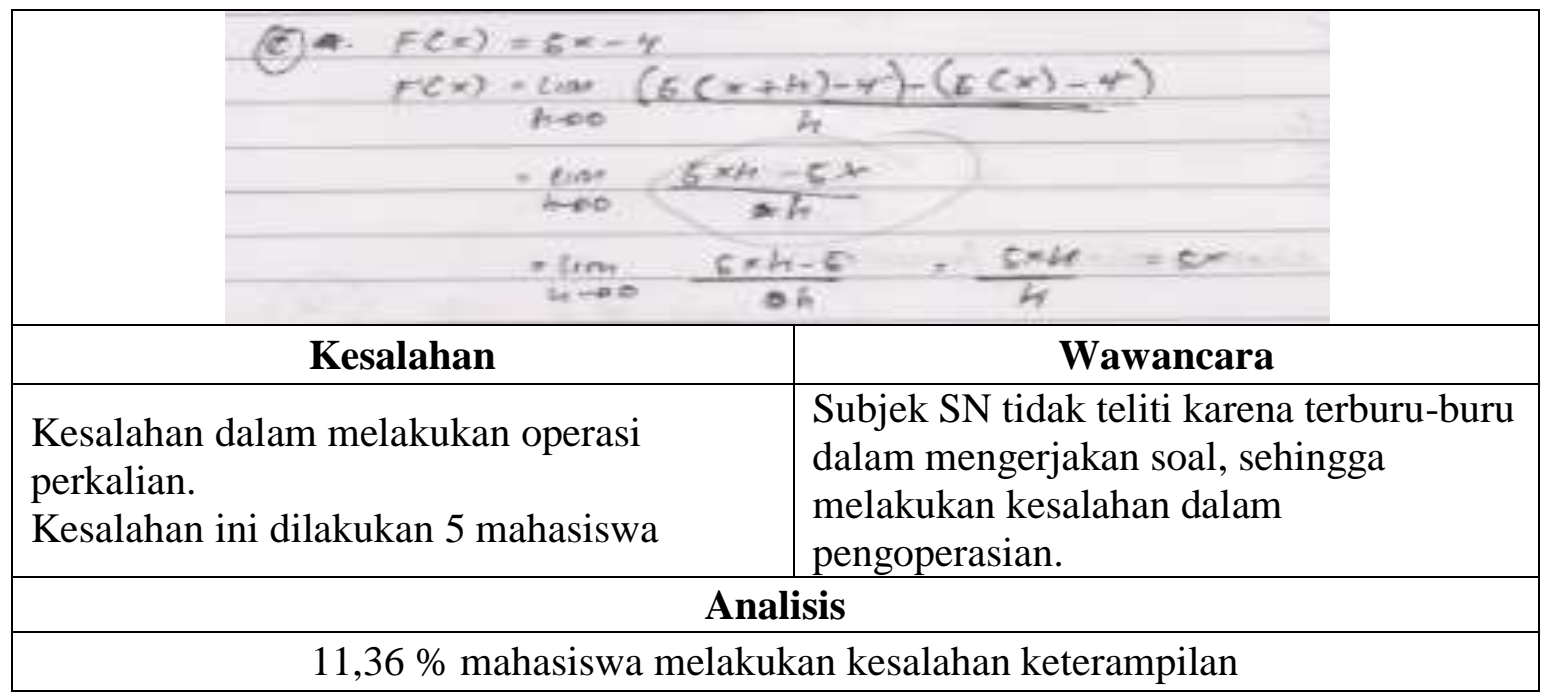

d. Kesalahan 4

Jawaban YU

\begin{tabular}{|c|c|}
\hline \multirow{2}{*}{\multicolumn{2}{|c|}{$a f(x)-5 x-4=\lim _{h \rightarrow 0} \frac{f(c+h)-f(c)}{h}$}} \\
\hline & \\
\hline \multicolumn{2}{|c|}{$\lim _{h \rightarrow 0} s(c+b)-4(5 x-4)$} \\
\hline & $\frac{h}{h}$ \\
\hline \multicolumn{2}{|c|}{ - $8 c+5 h-4-8 x+4$} \\
\hline \multicolumn{2}{|r|}{$\mathrm{h}$} \\
\hline \multicolumn{2}{|c|}{$=5 \mathrm{~h}$} \\
\hline \multicolumn{2}{|c|}{$\bar{h}$} \\
\hline Kesalahan & Wawancara \\
\hline $\begin{array}{l}\text { Tidak konsisten dalam penggunaan } \\
\text { variabel x dan c dan tidak menuliskan } \\
\text { limit. } \\
\text { Kesalahan ini dilakukan1 mahasiswa }\end{array}$ & $\begin{array}{l}\text { Subjek YU mengetahui bahwa untuk } \\
\text { variabel c dan x berbeda dan tidak dapat } \\
\text { dioperasikan, namun YU tetap } \\
\text { mengoperasikan keduanya karena bingung. }\end{array}$ \\
\hline \multicolumn{2}{|c|}{ Analisis } \\
\hline \multicolumn{2}{|c|}{$2,27 \%$ mahasiswa melakukan kesalahan fakta } \\
\hline
\end{tabular}

\section{e. Kesalahan 5}

Kesalahan tidak menjawab. Jumlah mahasiswa yang tidak menjawab sebanyak 1 orang.

Sedangkan jumlah mahasiswa yang menjawab benar sebanyak 17 orang. 
2. Kesalahan-kesalahan yang dilakukan mahasiswa untuk soalnomor 1b

a. Kesalahan 1

Jawaban AR

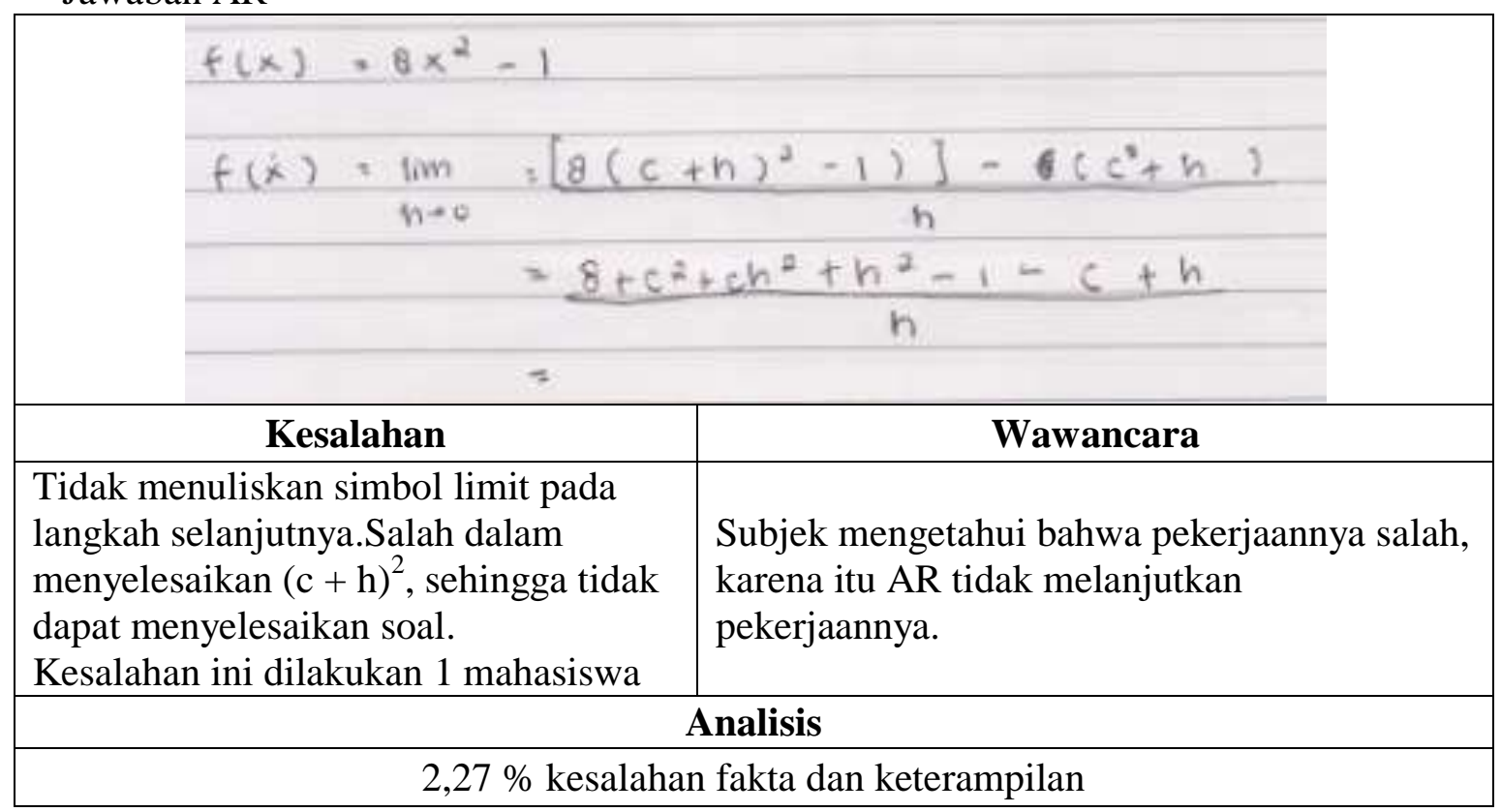

b. Kesalahan 2

Jawaban EC

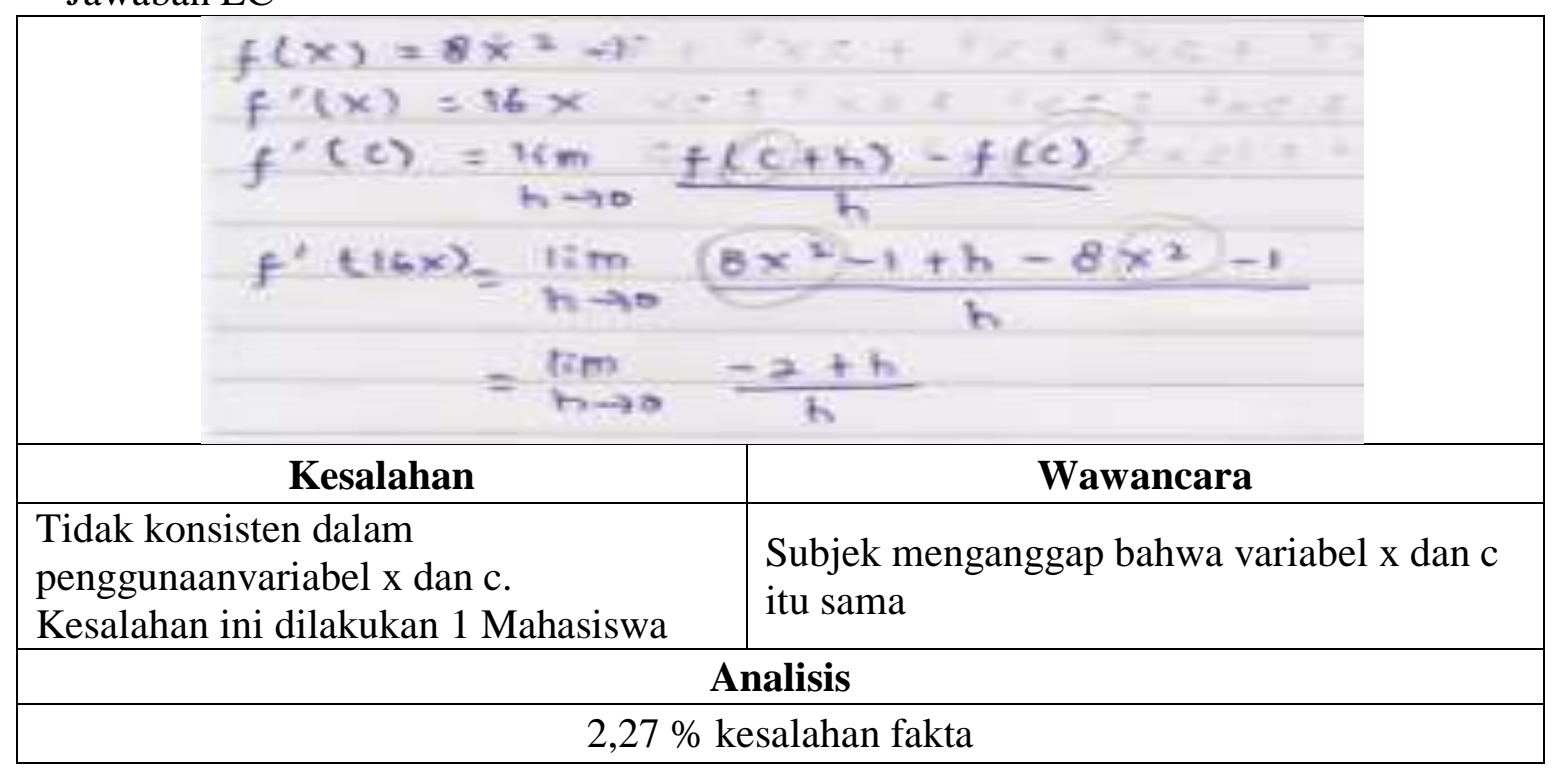

c. Kesalahan 3

Jawaban ST 


\begin{tabular}{|l|l|}
\hline \multicolumn{1}{|c|}{ Kesalahan } & \multicolumn{1}{c|}{ Wawancara } \\
\hline $\begin{array}{l}\text { Salah dalam operasiperkalian. } \\
\text { Kesalahan ini dilakukan 5 Mahasiswa }\end{array}$ & Subjek tidak teliti dalam mengoperasikan \\
\hline \multicolumn{2}{|c|}{ Analisis } \\
\hline \multicolumn{2}{|c|}{$11,36 \%$ kesalahan keterampilan } \\
\hline
\end{tabular}

d. Kesalahan 4

Jawaban JS

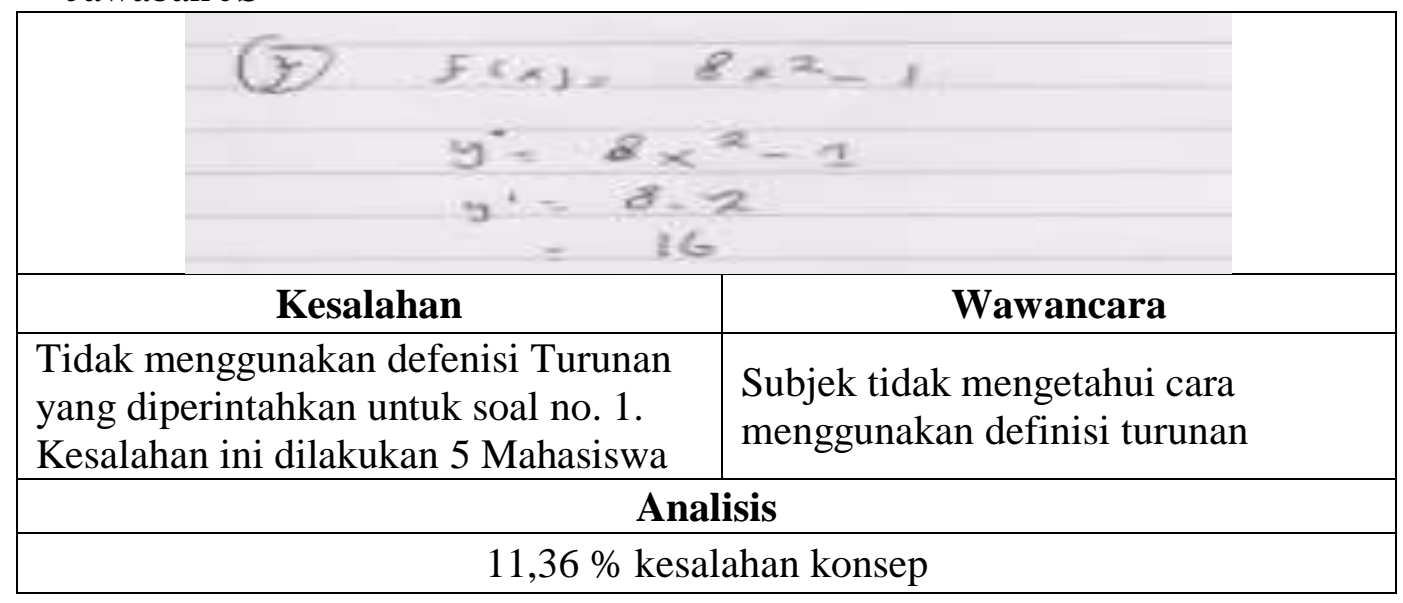

e. Kesalahan 5

Jawaban SN

\begin{tabular}{|c|c|}
\hline 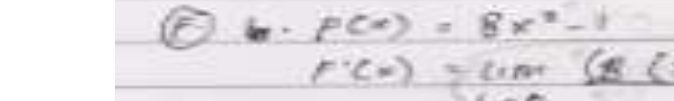 & $(+n)+h)-(8 x=-r)$ \\
\hline 600 & $t_{1}$ \\
\hline$-\lim _{600} 8$ & $\frac{i+8=i+h}{h}$ \\
\hline$=\ln$ & gu \\
\hline 3000 & h \\
\hline$=\lim _{\lim \infty} \&$ & 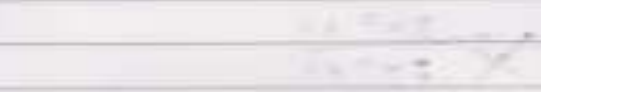 \\
\hline Kesalahan & Wawancara \\
\hline $\begin{array}{l}\text { Ditulis } \frac{[8(x+h)-1]-\left[x^{2}-1\right]}{h} \text { seharusnya } \\
\frac{\left[8(x+h)^{2}-1\right]-\left[x^{2}-1\right]}{h} \text {, atau tidak } \\
\text { menuliskan bilangan pangkat. } \\
\text { Kesalahan ini dilakukan } 12 \text { Mahasiswa }\end{array}$ & $\begin{array}{l}\text { Subjek mengetahui cara } \\
\text { menggunakan definisi turunan, } \\
\text { namun SN lupa menuliskan pangkat } \\
\text { karena kurang teliti }\end{array}$ \\
\hline Ana & sis \\
\hline $27,27 \%$ kesalah & keterampilan \\
\hline
\end{tabular}

\section{f. Kesalahan 6}

Kesalahan tidak menjawab soal. Jumlah mahasiswa yang tidak menjawab sebanyak 3 orang. Sedangkan jumlah mahasiswa yang menjawab benar sebanyak 12orang. 
3. Kesalahan-kesalahan yang dilakukan mahasiswa untuk soal nomor 1c

a. Kesalahan 1

Jawaban EC

\begin{tabular}{|c|c|}
\hline \multicolumn{2}{|l|}{$f(x)=\sqrt{3 x}$} \\
\hline \multicolumn{2}{|l|}{$=3 \times 3$} \\
\hline \multicolumn{2}{|c|}{$f^{\prime}(x)=3 / 2 x^{-1 / 2}$} \\
\hline \multicolumn{2}{|c|}{$f^{\prime}(c)=\lim _{h \rightarrow 0} \frac{f(c+h)-f(c)}{h}$} \\
\hline \multicolumn{2}{|c|}{$\left.f^{\prime}(x) x^{-3}\right) \lim _{h \rightarrow 0} 3 x^{3 / 2}+h-3 x^{5}$} \\
\hline$h \rightarrow 0$ & 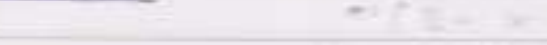 \\
\hline \multicolumn{2}{|r|}{ 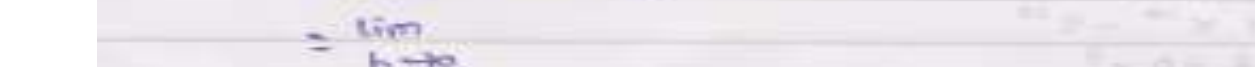 } \\
\hline \multicolumn{2}{|r|}{ 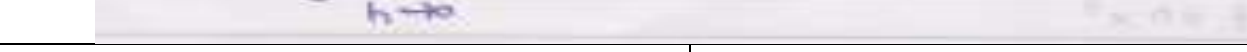 } \\
\hline Kesalahan & Wawancara \\
\hline $\begin{array}{l}\text { Tidak dapat melanjutkan penyelesaian. } \\
\text { Kesalahan ini dilakukan } 15 \text { orang } \\
\text { mahasiswa }\end{array}$ & $\begin{array}{l}\text { Subjek tidak melanjutkan } \\
\text { pekerjaannya karena tidak tau }\end{array}$ \\
\hline \multicolumn{2}{|c|}{ Analisis } \\
\hline \multicolumn{2}{|c|}{$39,09 \%$ kesalahan keterampilan } \\
\hline
\end{tabular}

b. Kesalahan 2

Jawaban FL

\begin{tabular}{|l|l|}
\hline \multicolumn{1}{|c|}{} & \multicolumn{1}{|c|}{ Wawancara } \\
\hline \multicolumn{1}{|c|}{ Kesalahan } \\
$\begin{array}{l}\text { Tidak menggunakan defenisi Turunan } \\
\text { yang diperintahkan untuk soal no. 1. } \\
\text { Kesalahan ini dilakukan 6 Mahasiswa }\end{array}$ & $\begin{array}{l}\text { Subjek bingung dengan cara } \\
\text { menggunakan definisi turunan }\end{array}$ \\
\hline \multicolumn{2}{|c|}{ Analisis } \\
\hline \multicolumn{2}{|c|}{ 13,64 \% kesalahan konsep } \\
\hline
\end{tabular}

c. Kesalahan 3

Jumlah mahasiswa yang tidak menjawab sebanyak 17 orang.

Selanjutnya jumlah mahasiswa yang menjawab benar sebanyak 1 orang.

4. Kesalahan-kesalahan yang dilakukan mahasiswa untuk soal nomor 1d

a. Kesalahan I

Jawaban EC

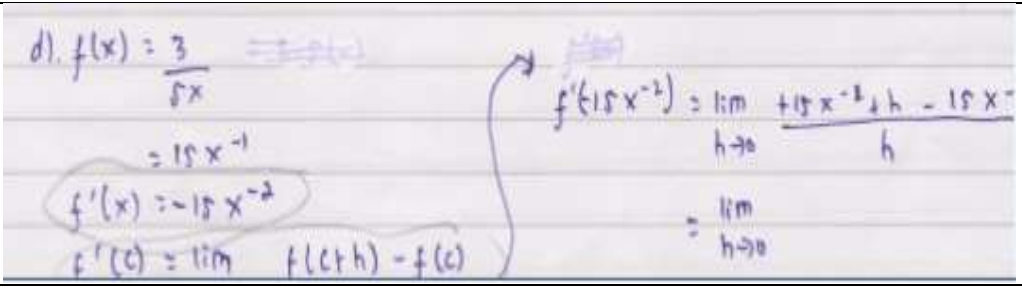




\begin{tabular}{|l|l|}
\hline \multicolumn{1}{|c|}{ Kesalahan } & \multicolumn{1}{|c|}{ Wawancara } \\
\hline $\begin{array}{l}\text { Salah dalam mengubah soal dan } \\
\text { mengganti f(c }+\mathrm{h}) . \\
\text { Kesalahan ini dilakukan 1 Mahasiswa }\end{array}$ & $\begin{array}{l}\text { Subjek hanya mengubah bentuk fungsinya } \\
\text { secara asal karena tidak paham }\end{array}$ \\
\hline \multicolumn{2}{|c|}{ Analisis } \\
\hline \multicolumn{2}{|c|}{$2,27 \%$ kesalahan konsep } \\
\hline
\end{tabular}

b. Kesalahan 2

Jawaban NS

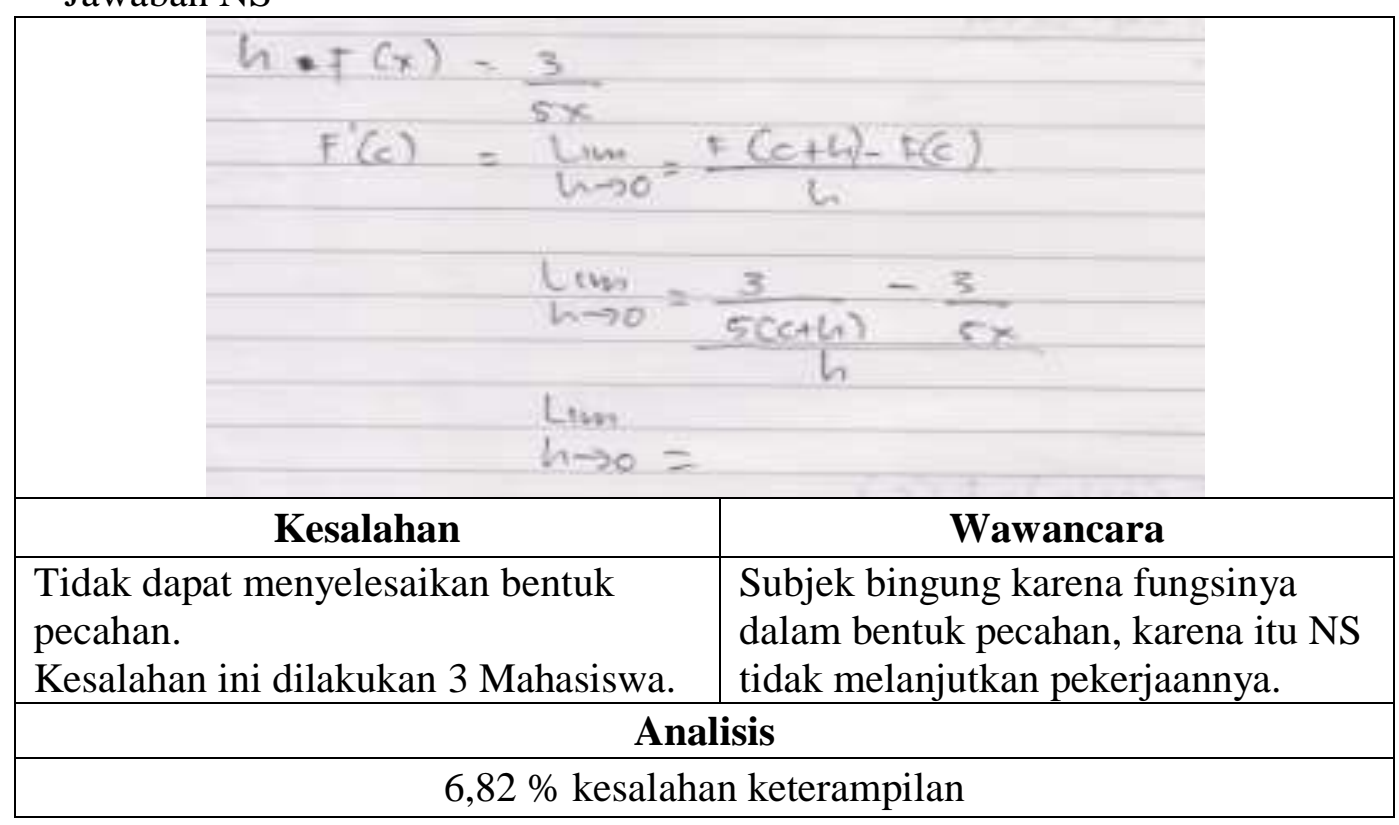

c. Kesalahan 3

Jawaban LE

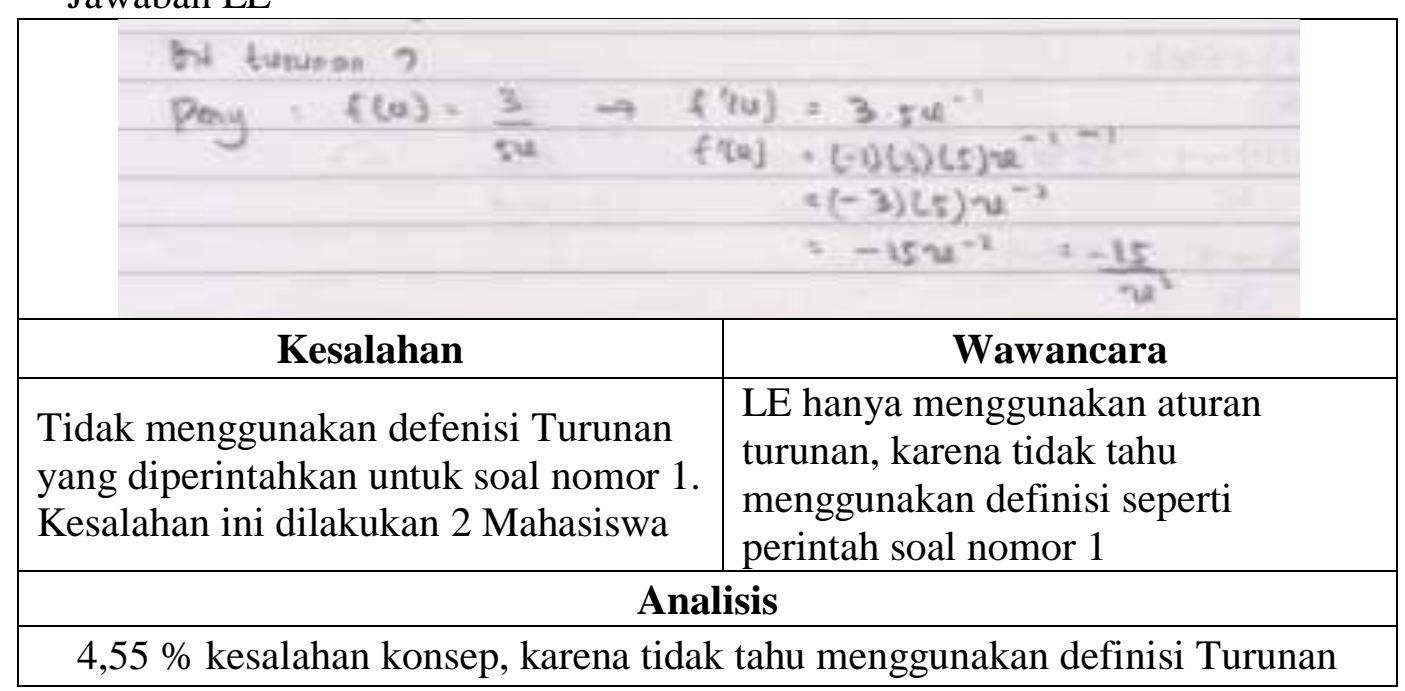


d. Kesalahan 4

Jawaban SN

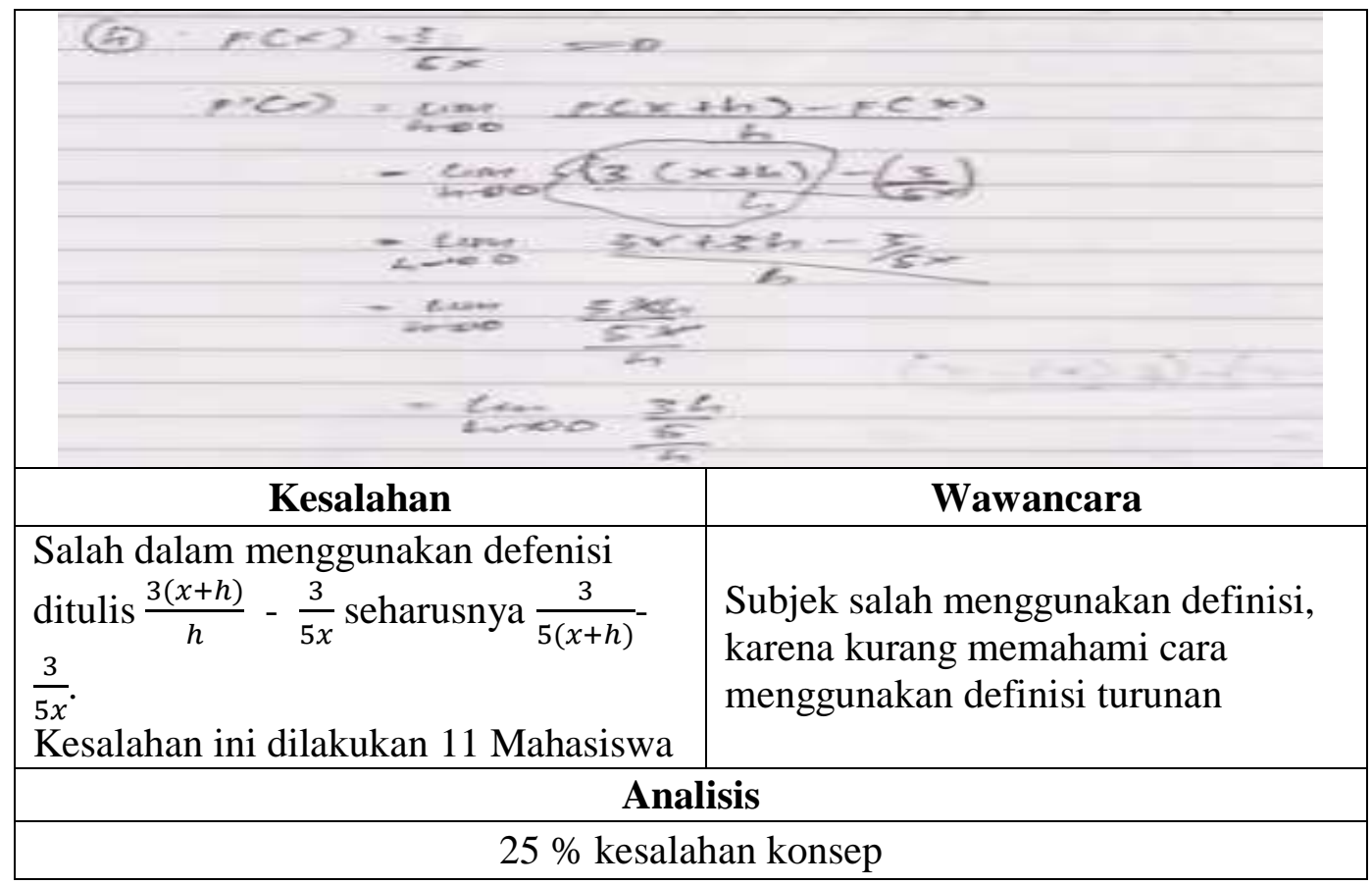

e. Kesalahan 5

Kesalahan tidak menjawab soal. Jumlah mahasiswa yang tidak menjawab sebanyak 25 orang, sedangkan jumlah mahasiswa yang menjawab benarsebanyak 2 orang.

\section{Kesalahan-kesalahan yang dilakukan mahasiswa untuk soal nomor 2a}

a. Kesalahan 1

Jawaban LK

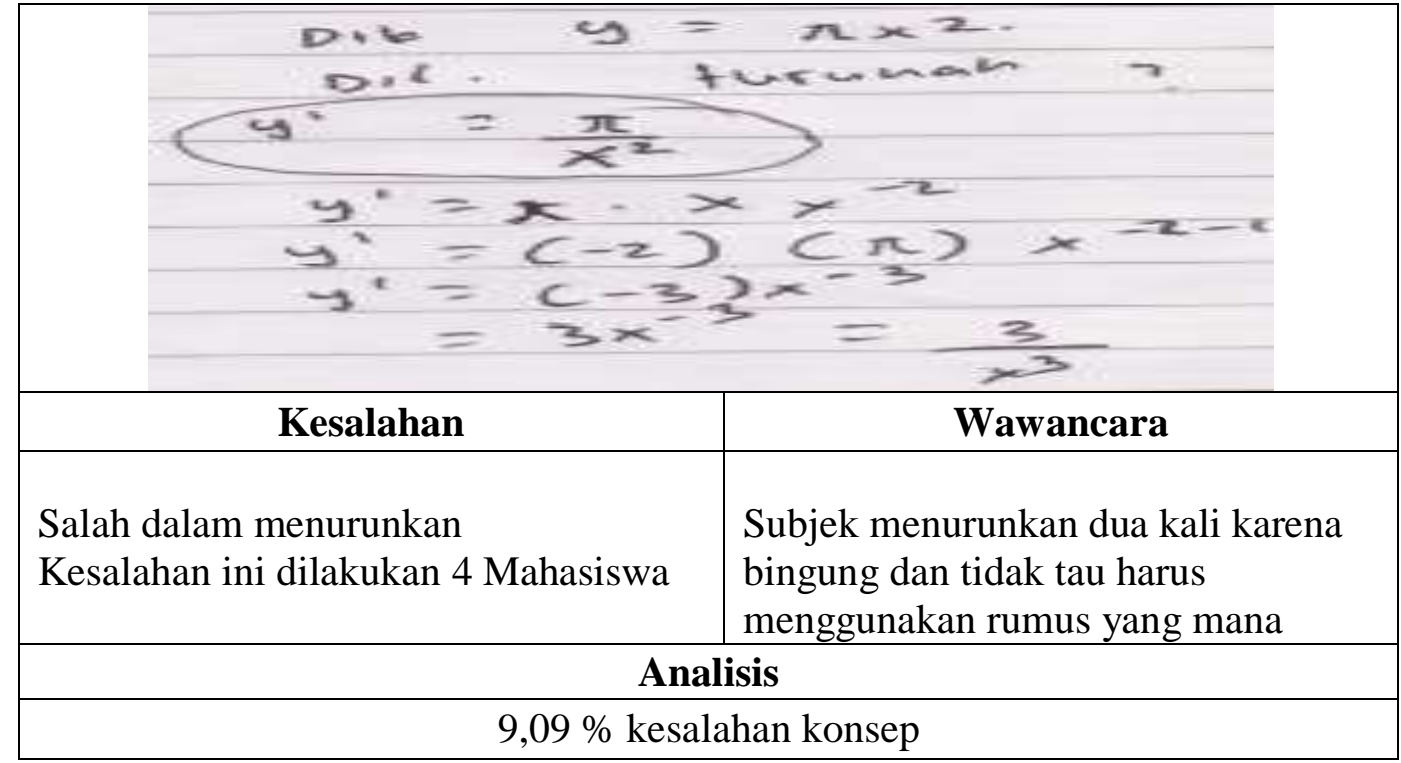


b. Kesalahan 2

Jawaban MK

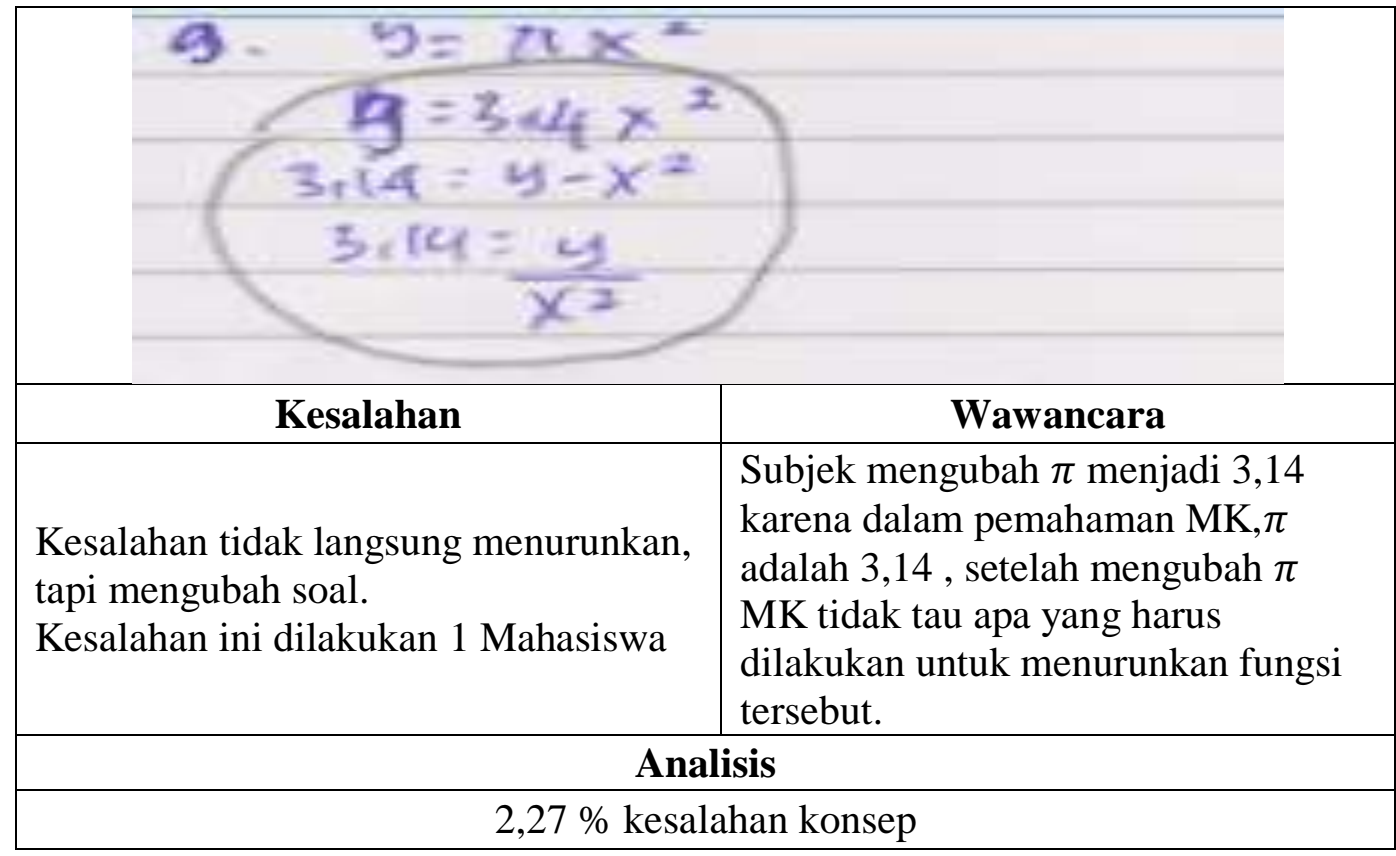

\section{c. Kesalahan 3}

Kesalahan tidak menjawab soal. Jumlah mahasiswa yang tidak menjawab sebanyak 13 orang, sedangkan jumlahmahasiswa yang menjawabbenarsebanyak 26 orang.

\section{Kesalahan-kesalahan yang dilakukan mahasiswa untuk soal nomor $\mathbf{2 b}$}

a. Kesalahan 1

Jawaban FL

\begin{tabular}{|c|l|}
\hline \multicolumn{2}{|c|}{$\theta=-\frac{2}{6 r}$} \\
\hline \multicolumn{2}{|c|}{ Kesalahan } \\
$\begin{array}{l}\text { Kesalahan dalam menurunkan. } \\
\text { Kesalahan ini dilakukan 11 Mahasiswa }\end{array}$ & $\begin{array}{l}\text { Subjek hanya menurunkan } \\
\text { penyebutnya karena menganggap } \\
\text { bahwa pembilang tidak memiliki } \\
\text { variabel sehingga tidak perlu } \\
\text { diturunkan. }\end{array}$ \\
\hline \multicolumn{1}{|c|}{ Analisis $\%$} \\
\hline \multicolumn{1}{|c|}{ kesalahan konsep } \\
\hline
\end{tabular}


b. Kesalahan 2

Jawaban HP

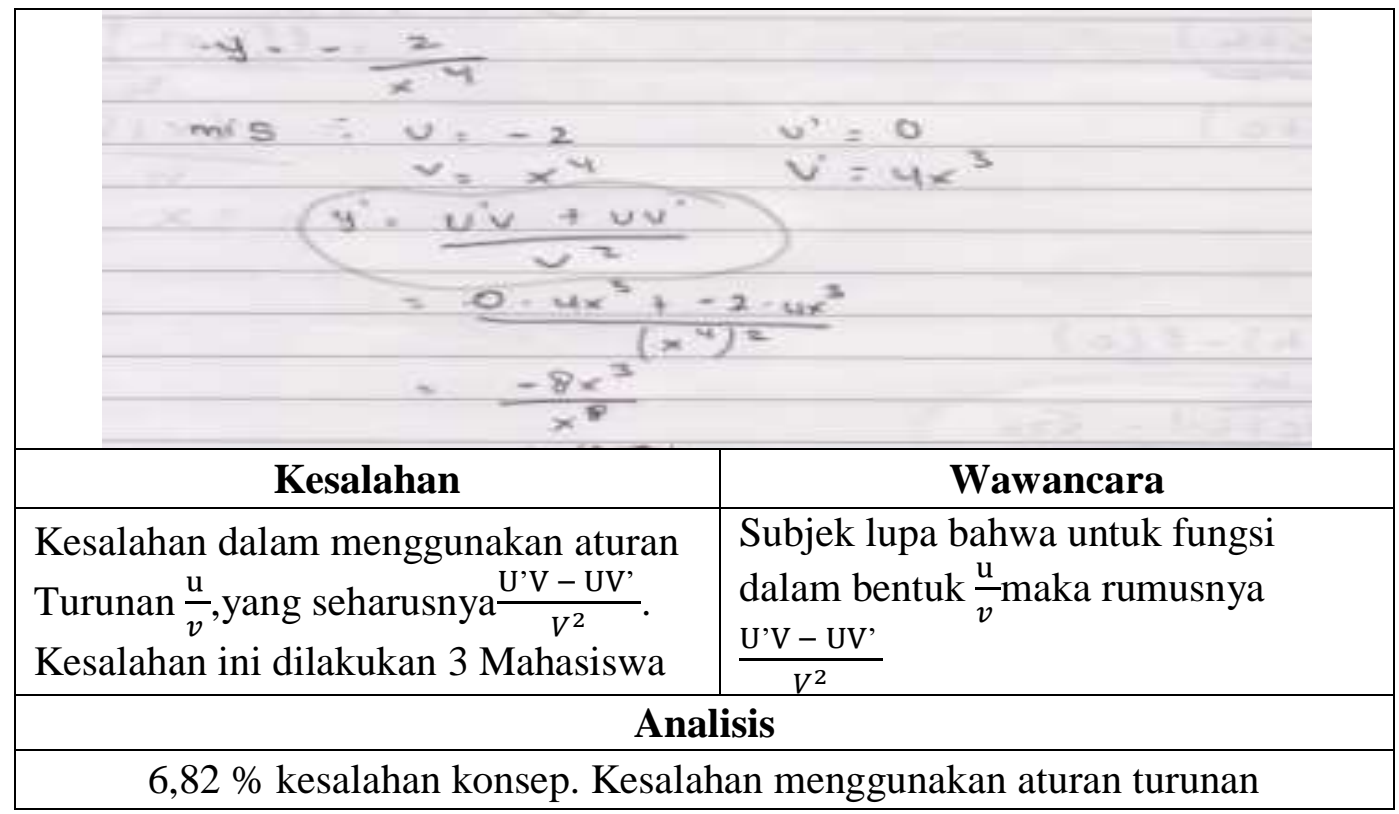

c. Kesalahan 3

Jawaban MH

\begin{tabular}{|c|c|}
\hline \multirow{2}{*}{\multicolumn{2}{|c|}{ b. $\quad a=-3$}} \\
\hline & \\
\hline \multicolumn{2}{|l|}{$y=x$. } \\
\hline Kesalahan & Wawancara \\
\hline $\begin{array}{l}\text { Tidak dapat menurunkan fungsi pecah. } \\
\text { Kesalahan ini dilakukan } 3 \text { Mahasiswa }\end{array}$ & $\begin{array}{l}\text { Subjek bingung cara menurunkan } \\
\text { fungsi tersebut karena dalam bentuk } \\
\text { pecahan. }\end{array}$ \\
\hline \multicolumn{2}{|c|}{ Analisis } \\
\hline
\end{tabular}

\section{d. Kesalahan 4}

Kesalahan tidak menjawab. Jumlah mahasiswa yang tidak menjawab sebanyak 20 orang.

Sedangkan jumlah mahasiswa yang menjawab benar sebanyak 7 orang.

7. Kesalahan-kesalahan yang dilakukan mahasiswa untuk soal nomor 2c

a. Kesalahan 1

Jawaban FE 


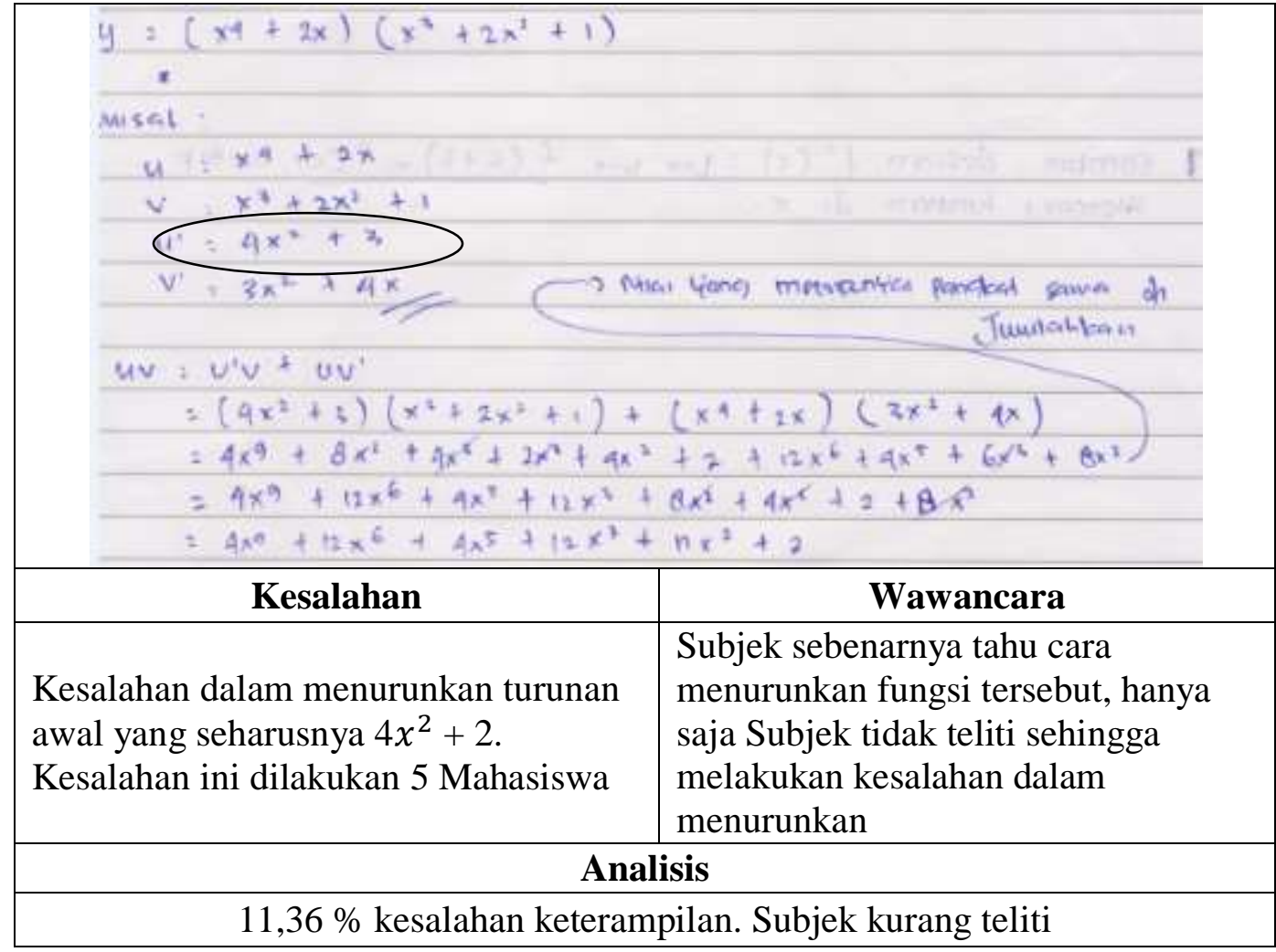

b. Kesalahan 2

Jawaban HP

\begin{tabular}{|l|l|}
\hline \multicolumn{3}{|c|}{ Kesalahan } & \multicolumn{1}{c|}{ Wawancara } \\
\hline $\begin{array}{l}\text { Salah menggunakan aturan turunan } \\
\text { perkalian dua fungsi } \\
\text { Kesalahan ini dilakukan 3 Mahasiswa }\end{array}$ & $\begin{array}{l}\text { Subjek lupa rumus turunan untuk } \\
\text { perkalian dua fungsi }\end{array}$ \\
\hline $\begin{array}{l}\text { 6,82 \% kesalahan konsep. Kesalahan menggunakan aturan turunan perkalian } \\
\text { dua fungsi }\end{array}$ \\
\hline
\end{tabular}


c. Kesalahan 3

Jawaban JS

\begin{tabular}{|c|l|}
\hline Kesalahan & \multicolumn{1}{|c|}{ Wawancara } \\
\hline$\frac{d y}{b}$ & $\begin{array}{l}\text { Subjek tidak tahu harus } \\
\text { menggunakan aturan turunan yang } \\
\text { mana, sehingga JS langsung } \\
\text { mengalikan }\end{array}$ \\
\hline $\begin{array}{l}\text { Tidak menggunakan aturan Turunan } \\
\text { dengan benar } \\
\text { Kesalahan ini dilakukan 15 Mahasiswa }\end{array}$ \\
\hline \multicolumn{2}{|c|}{ Analisis } \\
\hline 34,09\% kesalahan menggunakan aturan Turunan perkalian dua fungsi \\
\hline
\end{tabular}

d. Kesalahan 4

Jawaban LA

\begin{tabular}{|c|c|}
\hline \multicolumn{2}{|c|}{ (6) $y=\left(x^{4}+2 x\right)\left(x^{3}+2 x^{2}+1\right)$} \\
\hline \multicolumn{2}{|c|}{$\begin{aligned} u & =x^{4}+2 x \\
v & =x^{3}+2 x^{2}+1\end{aligned}$} \\
\hline \multicolumn{2}{|c|}{$v=x^{3}+2 x^{2}+1$} \\
\hline \multicolumn{2}{|c|}{$\begin{array}{l}u^{\prime}: 4 x^{3}+2 \\
y^{\prime}=3 x^{2}+4 x\end{array}$} \\
\hline \multicolumn{2}{|c|}{ 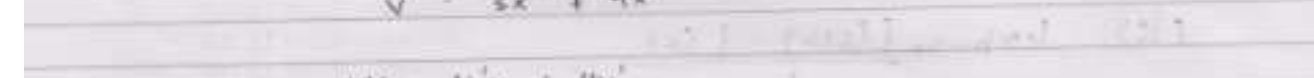 } \\
\hline \multicolumn{2}{|c|}{$\begin{aligned} \text { uv } & =\text { Ux } \\
& =\left(4 x^{2}+3\right)\left(x^{3}+2 x^{2}+1\right)+\left(x^{4}+2 x\right)\left(3 x^{2}+4 x\right) \\
& =\left(4 x^{3}\right)+\left(6 x^{3}\right)+4 x^{2}+2 x^{3}+6 x^{3}+4 x^{2}+2 x^{2}+12 x^{4}+4 x^{6} \\
& =\frac{4 x^{3}+12 x^{6}+4 x^{6}+12 x^{3}+12 x^{2}+2}{}\end{aligned}$} \\
\hline \multicolumn{2}{|l|}{ Kesalahan } \\
\hline $\begin{array}{l}\text { Kesalahan dalam melakukan operasi } \\
\text { perkalian. } \\
\text { Kesalahan ini dilakukan } 4 \text { Mahasiswa }\end{array}$ & $\begin{array}{l}\text { Subjek kurang teliti karena terburu- } \\
\text { buru }\end{array}$ \\
\hline \multicolumn{2}{|c|}{ Analisis } \\
\hline \multicolumn{2}{|c|}{ 9,09 \% kesalahan keterampilan. Kesalahan pekalian bentuk aljabar } \\
\hline
\end{tabular}

e. Kesalahan 5

Jumlah mahasiswa yang tidak menjawab sebanyak 14 orang.

Sedangkan jumlah mahasiswa yang menjawab benar sebanyak 5 orang.

\section{Kesalahan-kesalahan yang dilakukan mahasiswa untuk soal nomor $2 d$}

a. Kesalahan 1

Jawaban AP 


\begin{tabular}{|c|c|}
\hline \multicolumn{2}{|l|}{ (A) Di $=y \cdot \frac{5 x-4}{3 x^{2}}$} \\
\hline \multicolumn{2}{|l|}{ sx $-\frac{d y}{d y}=\cdots$ ? } \\
\hline \multicolumn{2}{|l|}{$y=\frac{5 x-y}{3 x^{2}+1}$} \\
\hline \multicolumn{2}{|r|}{$\frac{2 x-5 x-4+5 x+2}{x+3 x-1 x}$} \\
\hline \multicolumn{2}{|c|}{$3=\frac{d 9}{4}$} \\
\hline Kesalahan & Wawancara \\
\hline $\begin{array}{l}\text { Tidak menggunakan aturan Turunan } \\
\text { fungsi pecah dengan benar } \\
\text { Kesalahan ini dilakukan } 2 \text { Mahasiswa }\end{array}$ & $\begin{array}{l}\text { Subjek tidak tahu harus } \\
\text { menggunakan aturan turunan yang } \\
\text { mana, sehingga AP hanya } \\
\text { menurunkan penyebut dan } \\
\text { pembilangnya masing-masing }\end{array}$ \\
\hline \multicolumn{2}{|c|}{ Analisis } \\
\hline \multicolumn{2}{|c|}{$4,55 \%$ kesalahan konsep } \\
\hline
\end{tabular}

b. Kesalahan 2

Jawaban LE

\begin{tabular}{|c|c|}
\hline Prag $y=5 u-4=4$ & $u^{\prime} v-u v^{\prime}$ \\
\hline$\sqrt{3 u^{\prime}+1} v$ & $v^{2}$ \\
\hline $4+12-4 \quad 4^{\prime}=5$ & $=5\left(3 x^{2}+1\right)-(5 x-4)(6 u)$ \\
\hline$U^{\prime} \cdot w^{\prime}+1 \quad U^{\prime}=6 x$ & $\left(2 x^{2}+1\right)^{2}$ \\
\hline & $=\frac{15 u^{2}+1-3 a^{2}-2 y{ }^{2}}{\left(3 u^{2}+1\right)\left(3 a^{2}+1\right)}$ \\
\hline 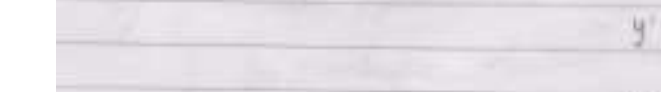 & $=-\frac{15 u^{2}-2 x u+1}{\left(3 u^{2}+1\right)\left(3 u^{2}+1\right)}$ \\
\hline & $=\frac{-15 u^{2}-24 x+1}{9 x^{4}+6 x^{2}+1}$ \\
\hline & $\left.=\frac{5}{3} u^{-1}-4 x^{\prime \prime}+1\right)=\frac{5}{3} u^{-1}-\frac{1}{4 x}+1$ \\
\hline Kesalahan & Wawancara \\
\hline $\begin{array}{l}\text { Kesalahan dalam pembagian bentuk } \\
\text { aljabar. } \\
\text { Kesalahan ini dilakukan } 12 \text { Mahasiswa }\end{array}$ & $\begin{array}{l}\text { Subjek melakukan kesalahan dalam } \\
\text { pembagian bentuk aljabar, karena } \\
\text { tidak paham dengan konsep } \\
\text { pembagian }\end{array}$ \\
\hline \multicolumn{2}{|c|}{ Analisis } \\
\hline \multicolumn{2}{|c|}{$27,27 \%$ kesalahan operasi pembagian bentuk aljabar } \\
\hline
\end{tabular}

c. Kesalahan 3

Jawaban SN

\begin{tabular}{|c|c|}
\hline$y=\frac{5 x-4}{3 x^{2}+1}$ & $=\left(3 x^{2}+1\right)\left(3 x^{2}+1\right)+(5 x-4) \cdot\left(3 x^{2}+1\right)$ \\
$\left(\frac{6 x-4}{3 x^{2}+1} \times \frac{3 x^{2}+1}{3 x^{2}+1}\right.$ & $=\left(9 x^{2}+8 x^{2}+3 x^{2}+1\right)+\left(15 x^{2}+12 x^{2}+12 x^{2}-3\right)$ \\
\hline Kesalahan & Wawancara \\
\hline
\end{tabular}




\begin{tabular}{|l|l|}
\hline $\begin{array}{l}\text { Kesalahan dalam memahami konsep } \\
\text { turunanfungsi pecah } \\
\text { Kesalahan ini dilakukan 8 Mahasiswa }\end{array}$ & $\begin{array}{l}\text { Subjek merasionalkan penyebut } \\
\text { karena tidak tahu cara menurunkan } \\
\text { fungsi bentuk pecahan }\end{array}$ \\
\hline \multicolumn{2}{|c|}{ Analisis } \\
\hline \multicolumn{2}{|c|}{$18,18 \%$ kesalahan konsep menurunkan fungsi pecah } \\
\hline
\end{tabular}

\section{d. Kesalahan 4}

Kesalahan tidak menjawab soal. Jumlah mahasiswa yang tidak menjawab sebanyak 20 orang.Sedangkan jumlah mahasiswa yang menjawab benar sebanyak 1 orang.

\section{Kesalahan-kesalahan yang dilakukan mahasiswa untuk soalnomor2e}

a. Kesalahan 1

Jawaban LE

\begin{tabular}{|c|c|}
\hline$k$ Dik $y=x^{*}$ & $\sin 4$ \\
\hline Dit tunnes ? & \\
\hline Peng $y=1$ & $e^{2} \sin 0$ \\
\hline Kesalahan & Wawancara \\
\hline $\begin{array}{l}\text { Salah dalam menggunakan konsep } \\
\text { turunan dan tidak melanjutkan kembali. } \\
\text { Kesalahan ini dilakukan } 7 \text { Mahasiswa }\end{array}$ & $\begin{array}{l}\text { Subjek bingung karena fungsinya } \\
\text { merupakan fungsi trigonometri }\end{array}$ \\
\hline Anal & isis \\
\hline $15,91 \%$ kesalahan konsep t & urunan fungsi trigonometri \\
\hline
\end{tabular}

b. Kesalahan 2

Jawaban EC

\begin{tabular}{|l|l|}
\hline \multicolumn{1}{|c|}{ e) $\frac{y}{d x}=x^{2} \sin x$} \\
\hline \multicolumn{2}{|c|}{ Kesalahan } \\
\multicolumn{1}{|c|}{$=-2 x \cos x$} \\
\hline $\begin{array}{l}\text { Hanya menurunkan sin x yang } \\
\text { seharusnya menggunakan aturan } \\
\text { turunan perkalian dua fungsi } \\
\text { Kesalahan ini dilakukan 2 mahasiswa }\end{array}$ & $\begin{array}{l}\text { Subjek beranggapan bahwa yang } \\
\text { perlu diturunkan hanya sin x nya saja }\end{array}$ \\
\hline \multicolumn{2}{|c|}{ Analisis } \\
\hline $\begin{array}{l}\text { 4,55 \% kesalahan konsep turunan perkalian fungsi aljabar dan fungsi } \\
\text { trigonometri }\end{array}$
\end{tabular}


c. Kesalahan 3

Jawaban HI

\begin{tabular}{|c|c|}
\hline \multicolumn{2}{|c|}{ 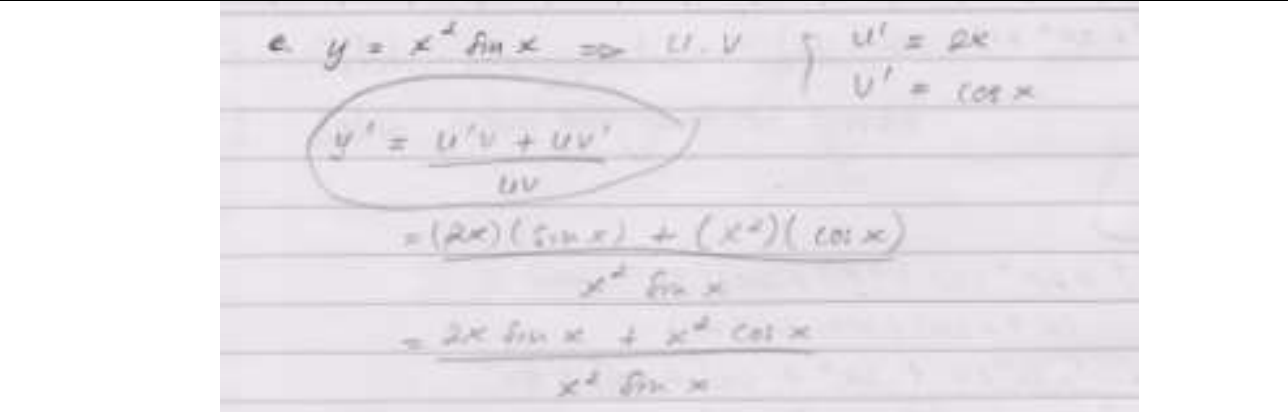 } \\
\hline Kesalahan & Wawancara \\
\hline $\begin{array}{l}\text { Kesalahan dalam menggunakan aturan } \\
\text { Turunan } \\
\text { Kesalahan ini dilakukan } 6 \text { Mahasiswa }\end{array}$ & $\begin{array}{l}\text { Subjek HI lupa cara menggunakan } \\
\text { aturan turunan }\end{array}$ \\
\hline \multicolumn{2}{|c|}{ Analisis } \\
\hline
\end{tabular}

\section{d. Kesalahan 4}

Jumlah mahasiswa yang tidak menjawab sebanyak 27 orang.

Sedangkan jumlah mahasiswa yang menjawab benar sebanyak 1 orang.

10. Kesalahan-kesalahan yang dilakukan mahasiswa untuk soalnomor2f

a. Kesalahan 1

Jawaban AP

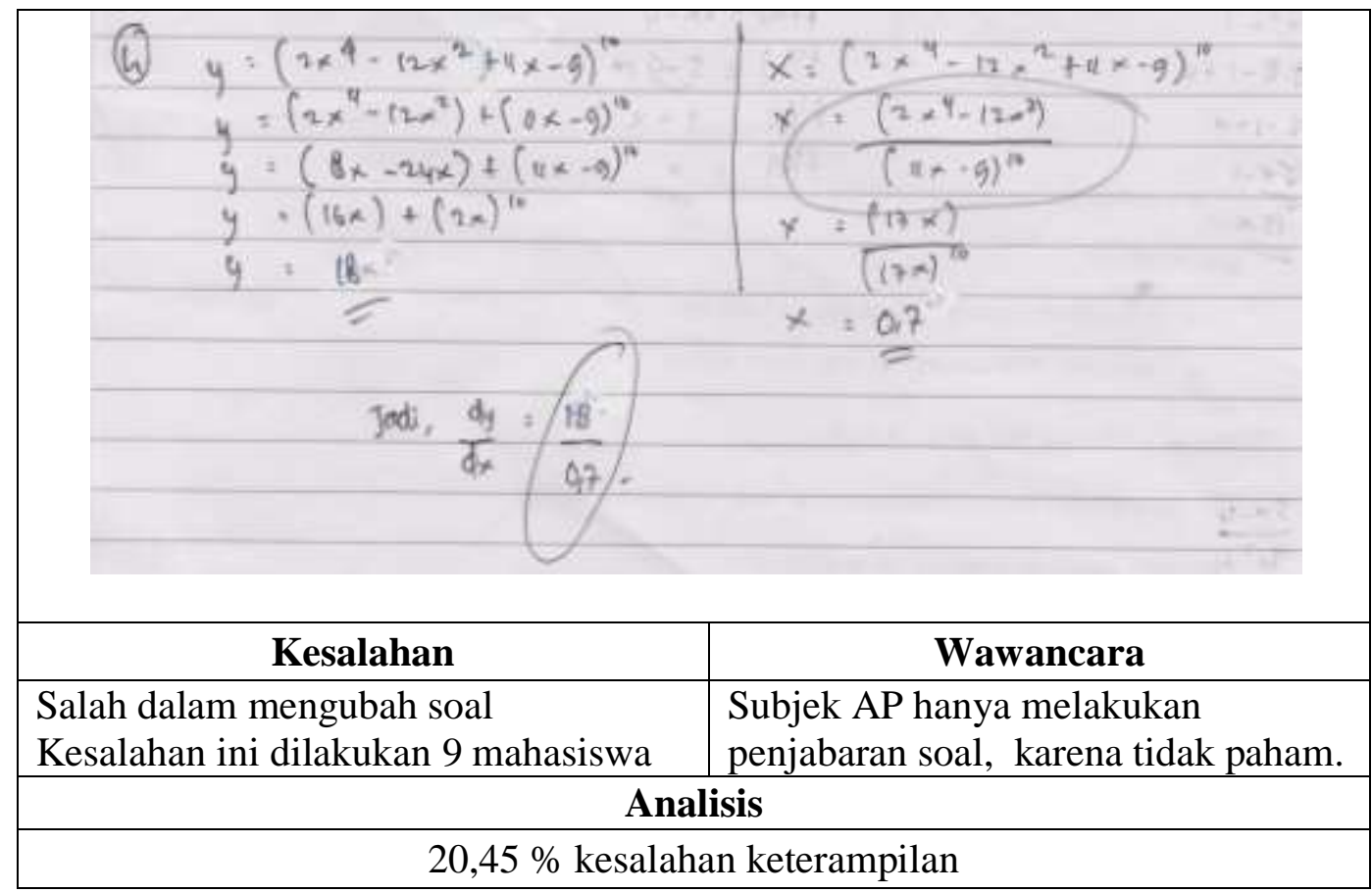


b. Kesalahan 2

Jawaban HI

\begin{tabular}{|c|c|}
\hline \multicolumn{2}{|c|}{ 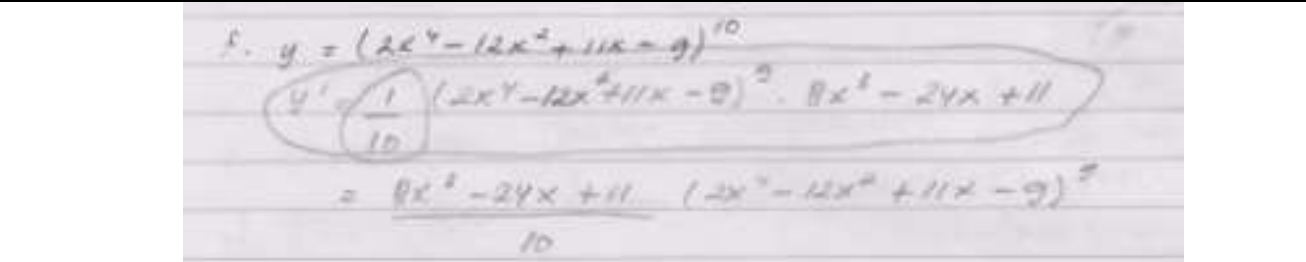 } \\
\hline Kesalahan & Wawancara \\
\hline $\begin{array}{l}\text { Ditulis } \frac{1}{10} \text { seharusnya } 10 \text {, tapi aturan } \\
\text { rantai dalam menurunkan sudah benar. } \\
\text { Kesalahan ini dilakukan } 4 \text { Mahasiswa }\end{array}$ & $\begin{array}{l}\text { Subjek HI memahami cara turunan } \\
\text { menggunakan aturan rantai, namun } \\
\text { HI tidak teliti dalam menjawab } \\
\text { sehingga melakukan kesalahan. }\end{array}$ \\
\hline \multicolumn{2}{|c|}{ Analisis } \\
\hline \multicolumn{2}{|c|}{ 9,09\% kesalahan keterampilan karena tidak teliti } \\
\hline
\end{tabular}

c. Kesalahan 3

Kesalahan tidak menjawab soal. Jumlah mahasiswa yang tidak menjawab sebanyak 28 orang. Sedangkan Jumlah mahasiswa yang menjawab benar sebanyak 1 orang.

\section{KESIMPULAN}

Berdasarkan hasil penelitian dan pembahasan, maka dapat disimpulkan bahwa kesalahan yang dilakukan mahasiswa Prodi Pendidikan Fisika semester I tahun ajaran 2017/2018, dalam menyelesaikan soal Turunan, yaitu:

1. Untuk soal nomor 1 :

a) tidak dapat mencari turunan satu fungsi menggunakan definisi.

b) salah dalam mensubsitusi $\mathrm{f}(\mathrm{x})$ menjadi $\mathrm{f}(\mathrm{x}+\mathrm{h})$

2. Untuk soal nomor2:

a) salah dalam menurunkan perkalian dua fungsi,

b) salah dalam menurunkan pembagi dua fungsi,

c) menganggap $\pi$ merupakan variabel (belum dapat membedakan variabel dan konstan)

\section{SARAN}

Saran yang dapat disampaikan antara lain:

1. Dosen sebaiknya selalu memperhatikan kesalahan-kesalan yang dilakukan oleh mahasiswa dan langsung memberikan tindak lanjut.

2. Mahasiswa memperbanyak latihan soal dengan tingkat kesulitan soal yang berbedabeda. 
92 AKSIOMA, Volume 10 Nomor 2, September 2021

\section{DAFTAR PUSTAKA}

Jaeng, M. (2015). Teori Belajar dan Inovasi Pembelajaran Matematika. Fakultas Keguruan dan Ilmu Pendidikan. Palu: Universitas Tadulako.

Miles, M.B., Huberman, A.M. \& Saldana J.(2014). Qualitative Data Analysis: A Methods Sourcebook Edition 3, Amerika: Sage publiscations.

Moleong, L. J. (2010). Metodelogi Penelitian kualitatif. Bandung: PT Remaja Rosdakarya.

Qodratillah, M.T, dkk. (2011). Kamus Bahasa Indonesia Untuk Pelajar. Jakarta: Badan Pengembangan dan Pembinaan Bahasa, Kementerian Pendidikan dan Kebudayaan.

Pawestri, U. (2013). Analisis Kesulitan pembelajaran Matematika dengan Pengantar Bahasa Inggris pada Materi Pokok bnetuk Logaritma kelas X Imersi SMA Negeri Karangpandan Karanganyar 2012/2013. Jurnal Pendidikan Matematika dan Matematika Solusi. [online]. 1, (1), 1-7. Tersedia:http://www.jurnal.fkip.uns. ac.id/index.php/matematika/login?source $=\% 2$ Findex.php\%2Fmatematika\%2Farticle \%2Fview\%2F1331\% [6 April 2017].

Purcell, E. (2010). Kalkulus. Edisi kesembilan Jilid 1. Jakarta: Erlangga.

Sugiyono, (2014). Metode Penelitian Pendidikan (Pendekatan Kuantitatif, Kualitatif dan $R \& D$ ), Bandung: Alfabeta.

Widodo dan Sri. A. (2013). Analisis Kesalahan dalam Pemecahan Masalah Divergensi Tipe Membuktikan Pada Mahasiswa Matematika. Jurnal Pendidikan dan Pengajaran [Online]. Jilid 46, No.2 Juli 2013, Hal 106-113. Tersedia:http://download.portal garuda.org/article.php?article $=145430 \& v a l=1324 \&$ title $=$ Analisis $\% 20$ Kesalahan $\% 20 \mathrm{~d}$ alam\%20Pemecahan\%20Masalah\%20Divergensi\%20Tipe\%20Membuktikan\%20pad a\%20Mahasiswa\%20Matematika. [6 April 2017]. 